\title{
The Role of Rural Tourism In Rural Development And Swot Analysis
}

\author{
Burcu Erdal and Şule Turhan
}

\begin{abstract}
Rural development is one of the leading issues that countries consider important. To ensure rural development, people living in rural areas need to improve in terms of socio-economic and cultural aspects, and increase the level of income and wealth. Rural tourism is one of the leading sectors contributing to rural development. Rural tourism is a tourism activity aiming to contribute to the economy of the region and to prevent migration from rural areas where the population is low and have been abandoned due to economic difficulties.

There are many positive effects of rural tourism such as providing additional income and new job opportunities to local people living in rural areas, slowing migration from rural areas to urban areas, increasing women's employment by enabling women to actively participate in work, protection of the local culture and increasing awareness of ownership. Additionally, there are also positive effects such as unifying the local people and the emergence of entrepreneurship spirit. However, rural tourism can meet expectancies and benefit the local community only if it integrates correctly with the local economy.

Rural tourism has negative effects as well as such positive effects. These include issues such as pollution of the environment and the destruction of nature, increased socio-cultural pressures, accommodation issues, and the potential for foreign investors to seize the region, excessive visitor traffic, and excessive vehicle and traffic intensity. Compared to the positive and negative effects, positive effects appear to be more prominent.

In this study, the positive and negative effects of rural tourism will be revealed and SWOT analysis will be conducted to show the strengths and weaknesses of opportunities and threats.
\end{abstract}

Keywords - Rural development, rural tourism, SWOT analysis, rural areas.

\section{INTRODUCTION}

Tourism can be defined as a set of activities that is caused by displacement of people is one of the important phenomenon of today's world. (Kizılarslan and Özyurt, 2012). Economic, social and technological developments in latest years in the world, have caused important changes in the perception and implementation of tourism. This change show itself as both quantitatively (tourism demand and preferences) and qualitatively (increase in tourist numbers and tourism incomes). So this change in tourism demand caused different tourism types to be considered. Rural tourism can be considered one of these (Ercan et all.).

Burcu Erdal, Res.Assist. Uludag University, Faculty of Agriculture, Department of Agricultural Economics, Görükle Bursa, Turkey.

Şule Turhan, Assos. Prof. Dr. Uludag University, Faculty of Agriculture, Department of Agricultural Economics, Görükle Bursa, Turkey.
Advantages of this type of tourism for the regions where it is implemented, necessitates a detailed evaluation for the areas that have attractions related to rural tourism. Choosing the right areas for rural tourism and creating a brand for rural tourism in these areas are very important for the success of rural tourism implementations and maximising the contribution of rural tourism for the local people. Because of this, seeing rural tourism as an element that will support local development instead of a profit making business can be considered a better approach

In this research the importance of rural tourism in rural development in Turkey, will be examined and an evaluation will be made using SWOT analysis.

\section{WHAT IS RURAL TOURISM?}

Natural and cultural aspects of rural areas historically, have been an answer to the recreational needs of people that especially live in cities. In the past, these people have travelled to rural areas mainly for daily recreational activities and visits for relatives. However, today, the attractiveness of rural life style, lack of limitations that cause stress and pressure and the possibility of activities that can make people feel free have caused rural areas to have intense visitations during weekends and holiday seasons. Thus, a tourism type that is called "rural tourism" has emerged. A short definition for rural tourism can be considered as "tourism type that is carried out in rural areas" (Ongun et all 2016).

Rural tourism is carried out in areas where agricultural activities take place and these activities are considered as a supply source for rural tourism (Uçar et all, 2010). Since rural tourism occurs in rural areas it can be considered a well-rounded and complex activity. Rural tourism depend on many activities such as farm tourism, green tourism and highland tourism as well as nature holidays, eco-tourism, shopping, skiing, nature trips with bicycles or horses, adventure, rafting, sports, thermal tourism, art, history and hunting and fishing also the ethnical structure of the area. In order to understand rural tourism understanding the elements of rural tourism is very important (Figure 2.) (Çeken et all 2007). 


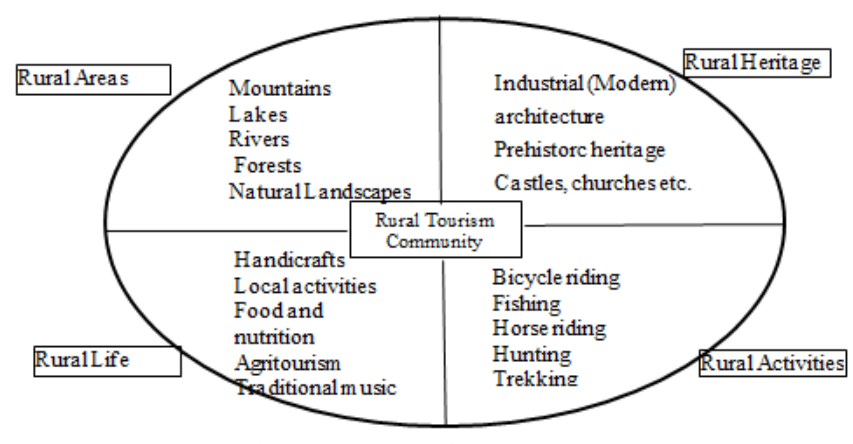

Fig. 1. Elements of Rural Tourism

There are also some basic characteristics of rural tourism. These can be listed as (Boyacioğlu, 2014);

- Rural tourism is a type of tourism based on environment, people and natural life,

- Authenticity and locality come to the forefront in rural tourism,

- Rural tourism is integrated and developed with local people,

- Rural tourism is a kind of tourism that preserves the diversity of agricultural and animal products and is intertwined with village life,

- Economic, environmental, social and cultural objectives are pursued in rural tourism,

- Rural tourism foresees to improve employment opportunities for local people,

- Rural tourism tries to minimize the negative effects that may occur with rural tourism.

\section{RURAL TOURISM IN RURAL DEVELOPMENT}

Rural development comprises of processes activities and organizations that try to develop the production, income and wealth

Rural development, comprises of processes, activities and organizations that try to improve the level of production, income and welfare in a way that changes the socio-economic and cultural structure of the people living in rural areas, to eliminate inequalities, to create the existing physical and social infrastructure in the urban areas in rural areas as well and to improve the usefulness of agricultural products. Rural tourism is a tourism type that can be integrated to other tourism types, it also can be considered integrated with the natural environment and agriculture (Soykan, 1999). When the definition and the characteristics of rural tourism is examined, it can be seen that rural tourism offers many benefits to the development of the areas they are implemented and to the company as a whole.

Rural tourism has many contributions to a country's economy and its development. However in order to ensure these contributions, rural tourism and its principles should be implemented in consciously. Rural tourism in rural areas should be done by putting sustainability to the front. And planning of rural tourism activities should be done without over usage of rural areas. Over usage can cause many difficulties for environment and natural elements and for the benefiters (Koç and Şahin 1999). Therefore the principles of rural tourism should be defined well.

The principles of rural tourism can be summarised as such;

- Development: Tourism development in rural areas should help to protect and uplift. For example, it can bring new uses to historic homes and additional use and income to farms; it can help improve the abandoned land and pave the way for new opportunities for rural access.

- Benefits: The efforts of tourists to make more use of the countryside should be directed to activities centered on the characteristics, beauty, culture, history and wild life of the countryside.

- Rural Economy: Investments in tourism should support the rural economy, however in order to avoid dense crowds and the damage and erosion of rural resources, activities should be spread to a larger geographic area and visits to a time frame beyond the peak periods.

- Design: Planning, identifying and managing new tourism developments should be appropriate to the landscape and, where possible, try to enrich the landscape.

- Conservation: Rural tourism beneficiaries should provide political and practical support to conservation policies and programs to contribute to the preservation and enrichment of the country's most valuable asset, the countryside.

- Marketing: In the marketing, promotion and information supplying of tourism industry people's understanding of rural areas and their interests should be deepened. . (Ün ve ark 2012).

\section{RURAL TOURISM OPPORTUNITIES IN TURKEY}

In latest years in Turkey, touristic beaches, villages around large cities, rural areas close to ancient architectural areas and villages near main roads have become important in terms of tourism. Country restaurants, shopping exhibitions, rural roads even fish farms have met daily tourists. Apart from individuals who visit these areas, travel agencies organize daily tour to these areas. Also projects that will revive old village ruins are being implemented (Ün and ark 2012).

Turkey in terms of both geographical and historical regions, has very favourable areas for rural tourism. For example Şirince village that is close to the Ephesus archaeological site, has many touristic activities in and around it and has unique opportunities for rural tourism. In Şirince many of the village's residents benefit from the tourism activities in the village. The village people can sell their handmade arts and crafts, handmade olive oil and soaps and many different products to tourists. Incomes from these and related activities can be used in the restoration of village and this is one of the main elements of rural tourism.

However in this example and in many other rural tourism areas in Turkey, planning and management activities for a sustainable rural tourism is missing. For a sustainable rural tourism, any issues related to the sustainable use of rural resources should be inherent in people's mind. For example in Sirince no research is done on the number of tourists, about the consumption levels of these tourists, their effect on the cultural, social structure in the area or their effect on environment. If 
these researches are not performed and any activities are not undertaken to minimise is not undertaken, it can be concluded that an important element of rural tourism is missing.

In Şirince, the fact that the old church which is one of the historical values of the village has not been repaired shows that rural tourism planning activities are not effective in the area. Even though many tourists visit the area, the people of the village still moves to the city rather than staying in their villages, the funds that are gained by rural tourism is not used in and for the village and lack of education for the local people about rural tourism also shows lack of planning and management activities.

In latest years, in the Black Sea Region of Turkey, highland tourism has been on the fore front. However in this area, a lack of planning and management activities can also be seen. For example in Uzungöl, it has been apparent that for many years construction projects had the potential to ruin the characteristics of the area, however no limitations were put on these for a very long while. Also another rural tourism attractions of this region Firtına Deresi (Storm Creek) has lost its many characteristic and lost its attractiveness as a rural tourism area due to a hydro-electric power plant built on it. However if any planning activities were undertaken these effects could have been foreseen.

In terms of natural and cultural resources Turkey has the potential to use these resources for rural tourism. Turkey, as a country with its climate and environment as well as being a country where different cultures and beliefs have been living together for many years has the potential to be an attractive rural tourism area. Being a developing country, large parts of Turkey's natural and rural cultural values are still alive, and many areas of Turkey, still has the potential for sustainable rural tourism (Yücel 2002).

\section{SWOT ANALYSIS FOR RURAL TOURISM IN TURKEY}

SWOT analysis for Turkey, where its strength, weaknesses, threats and opportunities for rural tourism is as follows;

\section{Strengths}

(a) Rich culture and tradition

(b) Rural areas with wide range of production

(c) Local government that is efficient and that has capacity (experience)

(d) Extensive knowledge and experience on the renewal of villages

(e) Young and knowledgeable human potential

(f) National plans and programmes

\section{Weaknesses}

(a) Decrease in population and migration in rural areas

(b) High unemployment rates in villages and counties

(c) Lack of coordination in investments and programming

(d) Inadequate restoration of structures symbolizing rural culture and heritage in rural tourism areas

(e) Inadequate infrastructure (roads, water services, health services, education...)

(f) Inadequate sewage and hygienic conditions (g) Quality problems in transportation devices

(h) Lack of infrastructure causes a lack of means for ensuring efficient production, quality and marketing for agricultural businesses

(1) Inadequate facilities and equipment in health and education areas,

(i) Inadequate promotion and advertising for existing assets and historical heritage

\section{Opportunities}

(a) Appropriate climate conditions for agricultural businesses

(b) Common use of information technologies

(c) Increase in environmental awareness

(d) Efficient regional development plans

(e) Connections of villages and districts with civil organizations

\section{Threats}

(a) Inadequate financial resources

(b) Inefficiency of expenditures

(c) Sector-based approach to planning and decision-making

(d) Low public participation

(e) Lack of sufficient influence of local and national economy - insufficient resources for strategies and planning,

(f) Increased migration as a result of decline in development and tourism revenues

The assessment of this analysis reveals that rural tourism is important for rural development and its contribution to rural people, that areas opened to rural tourism should be controlled, and environmental protection measures and education should be given to both local residents and tourists visiting the region (Torun 2013).

\section{RESULTS AND SUGGESTIONS}

In order to reveal Turkey's wealth in historical, cultural and natural diversity and offering these to the tourists requires an efficient use of marketing and promotional activities.

Rural tourism is the basis for tourism that is dependent on nature. However rural tourism has social, cultural and environmental effects. When planning activities are undertaken for rural tourism in a region these effects should be considered. Natural life should be preserved, natural and cultural values should not be damaged, life style and traditional values of the local people should not be corrupted, flora should not be damaged and the region should not be polluted visually. Rural tourism should uphold the principles of sustainable tourism. The capacity of the region should not be exceeded, and national control mechanisms should be applied for control. Both local and international tourists should be informed and educated, if needed public and civil organizations should carry out awareness campaigns in coordination with tourism agencies. An effective country rural tourism potential should be created, the government, social groups, private sector, academic and local organizations should work in a coordinated manner. 


\section{REFERENCES}

[1] Boyacıŏlu, E., Z., "Kırsal Turizmde Kadın Girişimciliği: Edirne Örneği”, International Journal of Social and Sciences, 4(2), 2014,82-90.

[2] Ceken, H., Karadağ, L., Dalgın, T., " Kırsal Kalkınmada Yeni Bir Yaklaşım Kırsal Turizm Ve Türkiye'ye Yönelik Teorik Bir Çalışma", Artvin Çoruh Üniversitesi Orman Fakültesi Dergisi, 8 (1), 2007,1-14

[3] Kızılaslan, N., Özyurt, Ç.. “ Sürdürülebilir Kırsal Kalkınmada Ekoturizmin Önemi: Tokat İli Örneği”, Gaziosmanpaşa Bilimsel Araştırma Dergisi 1 (2012), 2012,50-62

[4] Koç, N., Şahin, Ş. “ Kırsal Peyzaj Planlaması”, Ankara Üniversitesi Basımevi, 1999, Ankara.

[5] Ongun, U., Gövdere, B., Çiçek, U. “ The Evaluatıon With Swot Analysıs Of Yeşilova Rural Tourısm Potentıal", Suleyman Demirel University The Journal of Visionary, Year: 2016, Volume: 7, Number: 16, 2016, pp.75-88 https://doi.org/10.21076/vizyoner.265473

[6] Soykan, F “Doğal Çevre ve Kırsal Kültürle Bütünleşen Bir Turizm Türü: Kırsal turizm”. Anatolia Turizm Araştırmaları Dergisi (Türkçe). Yı1:10, Mart-Haziran 1999, 67-75.

[7] Uçar, M., Çeken, H. ve Ökten, Ş. “ Kırsal Turizm ve Kırsal Kalkınma: Fethiye Örneği”. Detay Yayıncılık, 2010, Ankara.

[8] Torun, E. “ Kırsal Turizmin Bölge İnsanına Katkıları”, KMÜ Sosyal ve Ekonomik Araştırmalar Dergisi 15 (24): 31-37, 2013, ISSN: 1309-9132, www.kmu.edu.tr

[9] Ün, E., Tutar, F., Tutar, E., Erkan, Ç. " Ekonomik Kalkınmada Kırsal Turizimin Rolü: Türkiye Örneği”. International Conference On Eurasian Economies. 2012.

[10] Yücel, Cengiz, "Turizmde Yükselen Değer: Ekoturizm”, TÜRSAB Ar-Ge,2002,

http://

www. tursab.org.tr/dosya/1023/02nieko_1023_1889046.pdf. Erişim: 14.11.2019 